\title{
INTENSITAS KERJA AKTIVITAS LAYANAN BONGKAR DI PELABUHAN PERIKANAN NUSANTARA SIBOLGA
}

\author{
Work Intensity of Unloading Service Activitiy at Sibolga Nusantara Fishing Port
}

\author{
Oleh: \\ Bastian Putrayadi Silalahi ${ }^{1 *}$, Budhi Hascaryo Iskandar², Fis Purwangka² \\ ${ }^{1}$ Mahasiswa Pascasarjana Program Studi Teknologi Perikanan Laut, FPIK-IPB \\ ${ }^{2}$ Staf Pengajar Program Studi Teknologi Perikanan Laut, FPIK-IPB \\ *Korespondensi: bastianipb@gmail.com
}

\begin{abstract}
ABSTRAK
Keselamatan adalah program penting yang sangat diperlukan di dunia kerja. Keselamatan dan Kesehatan Kerja adalah program untuk melindungi karyawan, lingkungan dan masyarakat sekitar bahaya kecelakaan di lingkungan kerja dan kondisi yang dapat mengubah kesehatan karyawan di tempat kerja. Penelitian ini bertujuan untuk mengetahui nilai kinerja aktivitas bongkar di Pelabuhan Perikanan Nusantara Sibolga dengan pekerja bongkar muat sebagai objek penelitian. Metode penelitian ini menggunakan observasi dan deskriptif kuantitatif. Teknik pengumpulan data dilakukan dengan mengambil data primer dan sekunder secara langsung, untuk mencari informasi tentang tingkat bahaya dan risiko yang terjadi selama kegiatan. Dalam penelitian ini, ada 7 tahap kegiatan bongkar muat yang dilakukan di Pelabuhan Perikanan Nusantara Sibolga. Pengoperasian layanan bongkar dilakukan dengan proses primer sebanyak 28 kegiatan primer dan 3 aktivitas sekunder dengan total aktivitas dari awal hingga akhir sebanyak 31 aktivitas total. Operasi kegiatan pembongkaran dari tahap awal hingga akhir membutuhkan 172 orang aktivitas dari intensitas kerja. Intensitas kerja primer tertinggi adalah pada tahap 1 (persiapan) dengan Indeks IKPi sebesar 0,2278 dari keseluruhan operasi aktivitas bongkar.
\end{abstract}

Kata kunci: Aktivitas bongkar, intensitas kerja, keselamatan kerja, Sibolga.

\begin{abstract}
Safety is an important program that is very necessary in the world of work. Occupational Safety and Health is a program to protect the employees, the environment and community around the danger of accidents in the work environment and conditions that can change the health of employees in the workplace. This study aims to determine value of the performance unloading service in Sibolga Nusantara Fishing Port with the workers of unloading service as research object. This research method used observation and descriptive quantitative. Data collection techniques conducted by taking primary and secondary data directly, to find information about level of hazards and risks that occur during the activity. In this research, there are 7 stages of unloading activities conducted at Sibolga Nusantara Fishing Port. The operation of unloading service was done by primary process as many as 28 primary activities and 3 secondary activities with total activity from the beginning until the end of 31 total activity. The operation of unloading activities from the initial stage to the end requires 172 person activity from work intensity. The highest intensity of work primary is at stage 1 (preparing) with IKPi Index of 0.2278 from the overall operation of unloading activity.
\end{abstract}

Keywords: Unloading activity, labor intensity, safety work, Sibolga. 


\section{PENDAHULUAN}

Keselamatan kerja merupakan program penting yang sangat diperlukan dalam dunia kerja saat ini. Berdasarkan Occupational Health and Safety Management Systems (OHSAS 18001:2007) defenisi Keselamatan dan Kesehatan Kerja (K3) adalah semua kondisi dan faktor yang dapat berdampak pada keselamatan dan kesehatan kerja tenaga kerja maupun orang lain (kontraktor, pemasok, pengunjung dan tamu) di tempat kerja. Program keselamatan dan kesehatan kerja diperlukan oleh perusahaan dan pekerja sebagai upaya untuk mencegah timbulnya kecelakaan dan penyakit akibat kerja, dengan mengenali potensi bahaya dan risiko kerja yang dapat menimbulkan kecelakaan.

Pelabuhan Perikanan Nusantara Sibolga memiliki berbagai macam aktivitas, salah satunya adalah aktivitas bongkar hasil tangkapan dan aktivitas muat kapal. Dalam kegiatan bongkar ikan hasil tangkapan dilakukan sepenuhnya oleh tim pekerja bongkar PPN Sibolga sedangkan untuk aktivitas muat untuk mengisi perbekalan kapal dilakukan oleh masing masing ABK kapal. Hal ini memiliki perbedaan dalam penelitian yang dilakukan oleh Maruli SS (2010) yang menyebutkan dalam hal pendaratan hasil tangkapan terhadap PPN Sibolga dari pendekatan armada yang melakukan aktivitas pembongkaran di tangkahan contoh dan PPN Sibolga serta dalam karya ilmiah Maruli SS (2010), penurunan hasil tangkapan dari dek kapal ke dermaga PPN Sibolga dilakukan oleh ABK (Anak Buah Kapal) atau buruh yang disewa. Perbedaan dari hasil penelitian tersebut dikarenakan PPN Sibolga saat ini sudah memiliki kebijakan terbaru mengenai perekrutan pekerja bongkar ikan hasil tangkapan.

Aktivitas bongkar di PPN Sibolga memiliki tim pekerja untuk melakukan bongkar ikan hasil tangkapan. Tim pekerja diperoleh dari lembaga SPSI yang di medasi oleh pihak PPN Sibolga. Dalam setiap bagian kerja, pekerja tim bongkar sudah diberikan surat keputusan No: 116/PPNS/KAPPNS/TU.210/I/2018 dari pihak pelabuhan untuk dapat bekerja di PPN Sibolga. Menurut Artoyo (1991) kebutuhan akan tenaga kerja pada suatu perusahaan ditentukan oleh program perusahaan baik jangka pendek maupun jangka panjang dan jabatan yang tersedia pada perusahaan tersebut. Tim bongkar pada aktivitas bongkar ikan hasil tangkapan terbagi dalam 3 bagian, yaitu bagian bongkar, bagian sortir dan bagian sorong. Masing masing bagian memiliki ruang lingkup kerja yang berbeda tetapi berada dalam satu alur mekanisme bongkar ikan hasil tangkapan. Ruang kerja untuk bagian bongkar berada diatas dek kapal, bagian sortir berada di dermaga pelabuhan dan bagian sorong berada di gedung TPI.

Potensi bahaya kecelakaan kerja secara umum dapat dilihat dari banyaknya ruang lingkup kerja dan juga banyak melibatkan jumlah pekerja bongkar serta aktivitas bongkar. Aktivitas bongkar memiliki beberapa tahapan yang harus dilakukan dan dalam setiap tahapan tersebut memiliki beberapa aktivitas yang dilakukan untuk mencapai goal dalam aktivitas bongkar ikan hasil tangkapan. Penelitian ini bertujuan untuk menentukan nilai intensitas kerja dalam seluruh aktivitas bongkar yang terbagi kedalam beberapa tahapan. Informasi tentang nilai intensitas kerja dalam aktivitas layanan bongkar ini diharapkan dapat digunakan sebagai salah satu acuan dalam menentukan langkah-langkah pengelolaan perikanan dalam bidang keselamatan kerja.

\section{METODE PENELITIAN}

Penelitian ini dilaksanakan pada bulan Oktober 2017 - Januari 2018. Lokasi penelitian adalah di Pelabuhan Perikanan Nusantara Sibolga, Provinsi Sumatera Utara dengan tenaga kerja bongkar hasil tangkapan sebagai objek penelitian. Metode penelitian yang digunakan adalah observasi dan deskriptif kuantitatif. Metode observasi dilakukan secara langsung dengan melakukan wawancara ke seluruh tenaga kerja aktivitas bongkar ikan hasil tangkapan. 
Penyajian data dilakukan berdasarkan kebutuhan optimasi pelayanan bongkar muatan di dermaga PPN Sibolga, diantaranya data yang berhubungan dengan laju pelayanan bongkar, jumlah pekerja layanan bongkar, fasilitas yang digunakan oleh pekerja layanan bongkar. Laju pelayanan bongkar hasil tangkapan ditinjau dari proses lama waktu bekerja pekerja. Data sekunder digunakan untuk melihat besaran aktivitas perikanan di pelabuhan yang mendukung dan optimasi fasilitas pelayanan di PPN. Data yang diperoleh disajikan dalam bentuk Tabel 1.

Tabel 1 Jenis data dan sumber data

\begin{tabular}{|c|c|c|}
\hline No & Jenis Data & Sumber Data \\
\hline \multirow[t]{4}{*}{1} & Tim bongkar & \\
\hline & 1. Tenaga kerja & 1. Data jumlah pekerja layanan bongkar \\
\hline & 2. Fasilitas tenaga kerja & 2. Alur pelayanan bongkar \\
\hline & 3. Lingkungan Kerja & $\begin{array}{l}\text { 3. Bagian pekerja bongkar perikanan di PPN } \\
\text { Sibolga }\end{array}$ \\
\hline \multirow[t]{7}{*}{2} & Tahapan aktivitas bongkar ikan hasil & 1. Persiapan bongkar di dermaga pelabuhan \\
\hline & tangkapan & $\begin{array}{l}\text { 2. Penanganan hasil tangkapan oleh tim bongkar } \\
\text { ikan dari palka kapal }\end{array}$ \\
\hline & & $\begin{array}{l}\text { 3. Pembagian ikan berdasarkan jenis, kualitas dan } \\
\text { ukuran ikan hasil tangkapan }\end{array}$ \\
\hline & & $\begin{array}{l}\text { 4. Pengangkutan ember berisi ikan untuk } \\
\text { ditimbang }\end{array}$ \\
\hline & & $\begin{array}{l}\text { 5. Pemindahan ember menggunakan alat angkut } \\
\text { sorong ke gedung TPI }\end{array}$ \\
\hline & & $\begin{array}{l}\text { 6. Distribusi ikan hasil tangkapan di gedung ke } \\
\text { pedagang kecil/pengecer dan perusahaan }\end{array}$ \\
\hline & & $\begin{array}{l}\text { 7. Penggabungan ikan yang seragam berdasarkan } \\
\text { kategori jenis, ukuran dan kualitas ke dalam fiber } \\
\text { yang berbeda kategori }\end{array}$ \\
\hline 3 & Perlengkapan bongkar & Peralatan alat bongkar, fasilitas pendukung \\
\hline \multirow[t]{3}{*}{4} & Data informasi pelabuhan & 1. Data fasilitas dan peralatan PPN Sibolga \\
\hline & & 2. SOP yang terkait di PPN Sibolga \\
\hline & & 3. Layout Pelabuhan Perikanan Nusantara Sibolga. \\
\hline
\end{tabular}

Data pada tabel di atas merupakan data primer dan sekunder. Data primer diperoleh secara langsung melalui hasil observasi dan wawancara di lokasi kerja yang berguna untuk mengetahui aktivitas yang dilakukan oleh tim bongkar dan keadaan lingkungan tempat kerja. Data sekunder diperoleh dari penelusuran pustaka melalui stakeholder yang berkaitan dengan aktivitas bongkar hasil tangkapan di Pelabuhan Perikanan Nusantara Sibolga. Pengambilan data juga dilakukan wawancara dengan sensus pekerja tim bongkar ikan hasil tangkapan secara menyeluruh yang berjumlah 41 orang.

Sifat aktivitas dalam pengertiannya terbagi atas dua bagian yaitu terdiri dari aktivitas primer dan aktivitas sekunder. Aktivitas primer harus dilakukan sesuai tahapan berdasarkan urutan dalam aktivitas tersebut dan tidak dapat dilakukan pada urutan dalam tahapan lain sedangkan aktivitas sekunder dapat dikerjakan pada urutan aktivitas lain. Perhitungan total aktivitas kerja pada saat melakukan pengoperasian alat tangkap yang dijumlahkan adalah nilai dari banyaknya aktivitas primer dan sekunder pada masing-masing tahapan aktivitas yang dilakukan (Handayani 2014). Perhitungan nilai aktivitas kerja pada pengoperasian alat tangkap diasumsikan sama dengan aktivitas pengoperasian bongkar hasil tangkapan di pelabuhan. Untuk perhitungan total aktivitas kerja tim 
bongkar dijumlahkan dari banyaknya aktivitas primer dan sekunder pada masing-masing tahapan aktivitas:

$$
\begin{gathered}
\text { Total aktivitas kerja }=\mathrm{f} \text { (aktivitas primer, aktivitas sekunder) } \\
\text { sehingga dapat dijabarkan menjadi }
\end{gathered}
$$

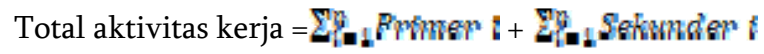

Dengan

$\mathrm{i}=$ Tahap ke $-1,2 \ldots \ldots, \mathrm{n}$

$\mathrm{n}=$ Jumlah tahap aktivitas

Nilai intensitas kerja dalam penelitian ini adalah intensitas kerja primer dan sekunder dimana kedua intensitas kerja tersebut dihitung untuk mendapatkan nilai total. Intensitas kerja yang dimaksud dalam tulisan ini merupakan ukuran jumlah pekerja (orang) yang terlibat dalam satu aktivitas. Intensitas kerja primer dan sekunder dihitung untuk mendapatkan nilai total intensitas kerja. Berikut dilampirkan rumus perhitungan intensitas kerja menurut Handayani (2014) yang digunakan dalam penelitian ini.
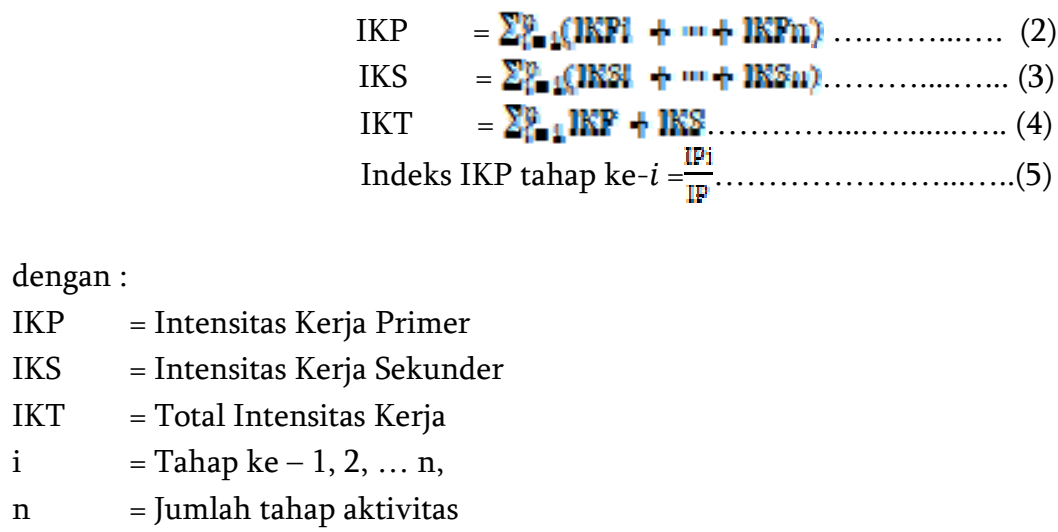

Perhitungan intensitas kerja diatas dapat dijelaskan pada persamaan (2) dan (3) menghasilkan Intensitas Kerja Total (IKT) (4). Indeks Intensitas Kerja Primer (IKP) digunakan dalam menentukan ranking dari setiap tahapan bongkar. Nilai IKP masing-masing tahap aktivitas diurutkan dari nilai IKP terbesar hingga terkecil. Menurut Silaban (2010), terdapat hubungan yang sangat signifikan (* untuk $\mathrm{p}<0.01$ ) antara jumlah keterlibatan tenaga kerja dengan jumlah kecelakaan kerja. IKP yang paling besar menunjukkan ranking aktivitas paling tinggi dimana keterlibatan tenaga kerja bongkar paling besar.

Work Intensity (intensitas kerja) sebagian besar diteliti melalui studi kuantitatif dengan menggunakan instrumen survei skala besar dan telah dipahami sebagai serangkaian pengukuran seperti: kecepatan kerja (pace of work); kebutuhan untuk memenuhi tenggang waktu yang ketat; seberapa keras atau seberapa banyak usaha pekerja dimasukkan ke dalam pekerjaan mereka (Hamilton 2007).

\section{HASIL DAN PEMBAHASAN}

Tenaga kerja tim bongkar merupakan salah satu komponen vital dalam aktivitas pelabuhan. Tenaga kerja tim bongkar di Pelabuhan Perikanan Nusantara Sibolga terbagi dalam 3 (tiga) bagian kerja. Setiap bagian kerja memiliki tahapan dan intensitas kerja yang berbeda. Untuk tenaga kerja 
bagian bongkar dan bagian sorong mempunyai tugas ganda dalam bekerja, yaitu untuk bongkar ikan hasil tangkapan dan memuat perbekalan nelayan ke kapal.

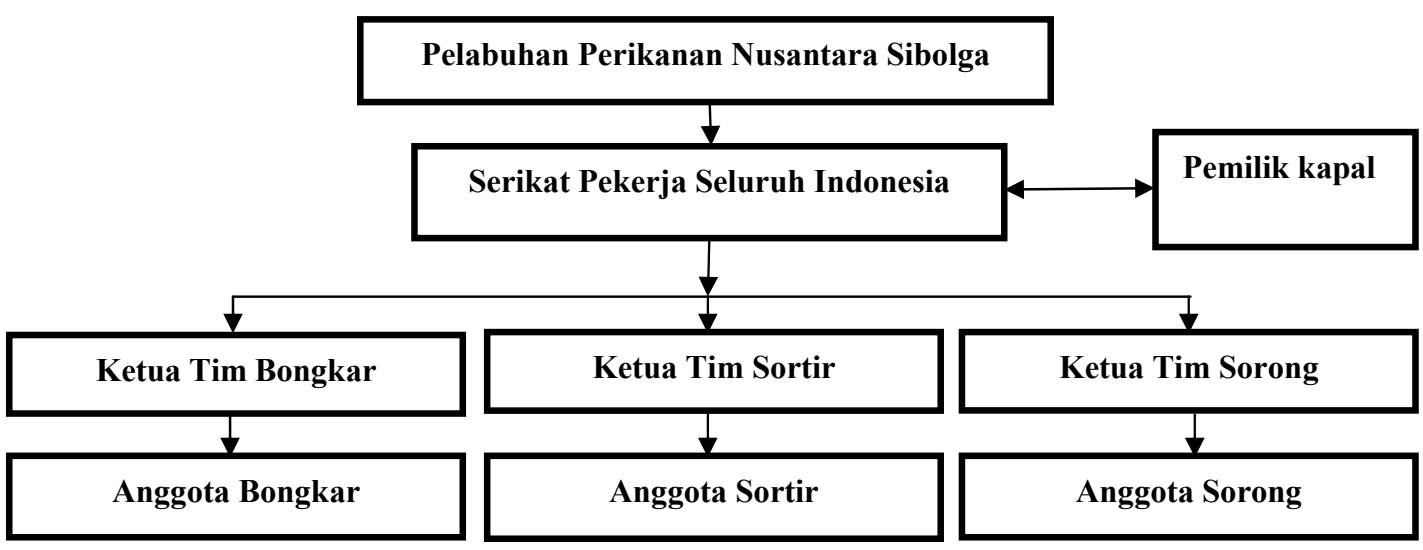

Sumber: Hasil observasi penelitian

Gambar 1 Bagan Tenaga Kerja Bongkar di PPN Sibolga

Tabel 2 Jabatan dan Tugas Tim Bongkar

\begin{tabular}{|c|c|c|c|}
\hline No & Jabatan & Jumlah & Tugas \\
\hline 1 & $\begin{array}{l}\text { Ketua Tim } \\
\text { Bongkar; }\end{array}$ & 1 orang & $\begin{array}{l}\text { Ketua mendata anggota bongkar dan membagi tugas serta posisi } \\
\text { di atas kapal }\end{array}$ \\
\hline 2 & Ketua Tim Sortir; & 1 orang & $\begin{array}{l}\text { Ketua mendata anggota sortir dan membagi tugas serta posisi di } \\
\text { meja sortir }\end{array}$ \\
\hline 3 & $\begin{array}{l}\text { Ketua Tim } \\
\text { Sorong }\end{array}$ & 1 orang & $\begin{array}{l}\text { Ketua mendata anggota sorong dan membagi tugas anggota sesuai } \\
\text { posisi }\end{array}$ \\
\hline 4 & Anggota Bongkar & 12 orang & $\begin{array}{l}\text { Mengikuti perintah dan arahan dari ketua tim untuk } \\
\text { membongkar ikan diatas kapal. }\end{array}$ \\
\hline 5 & Anggota Sortir & 12 orang & $\begin{array}{l}\text { Anggota menyortir/membagi ikan berdasarkan kualitas dan jenis } \\
\text { ikan hasil tangkapan }\end{array}$ \\
\hline 6 & Anggota Sorong & 14 orang & $\begin{array}{l}\text { Menimbang, mengantar/mendistribusikan ikan hasil tangkapan } \\
\text { langsung ke mobil perusahaan pengelola atau ke pedagang/ } \\
\text { pengecer. }\end{array}$ \\
\hline
\end{tabular}

Dari Tabel 2 diatas dapat dilihat jabatan, jumlah serta tugas kerja tim bongkar ikan hasil tangkapan. Pada ketua tim, masing masing berjumlah satu orang dari setiap bagian kerja. Anggota dari bagian bongkar berjumlah 12 orang, anggota sortir berjumlah 12 orang dan anggota sorong berjumlah 14 orang. Ketua tim dari masing masing bagian memberikan arahan kepada anggota untuk melaksanakan perintah dan tugas yang diberikan. Pada saat pekerjaan sedang berlangsung, setiap ketua tim merangkap pekerjaan nya juga menjadi anggota dari masing masing bagian kerja dan ikut bekerja bersama dengan anggota dengan nilai kerja yang sama dalam mekanisme bongkar. Mekanisme bongkar ikan di identifikasi dari perjalanan dan tata cara bongkar ikan hasil tangkapan dari kapal hingga penanganan akhir seperti pada Gambar 2 berikut. 


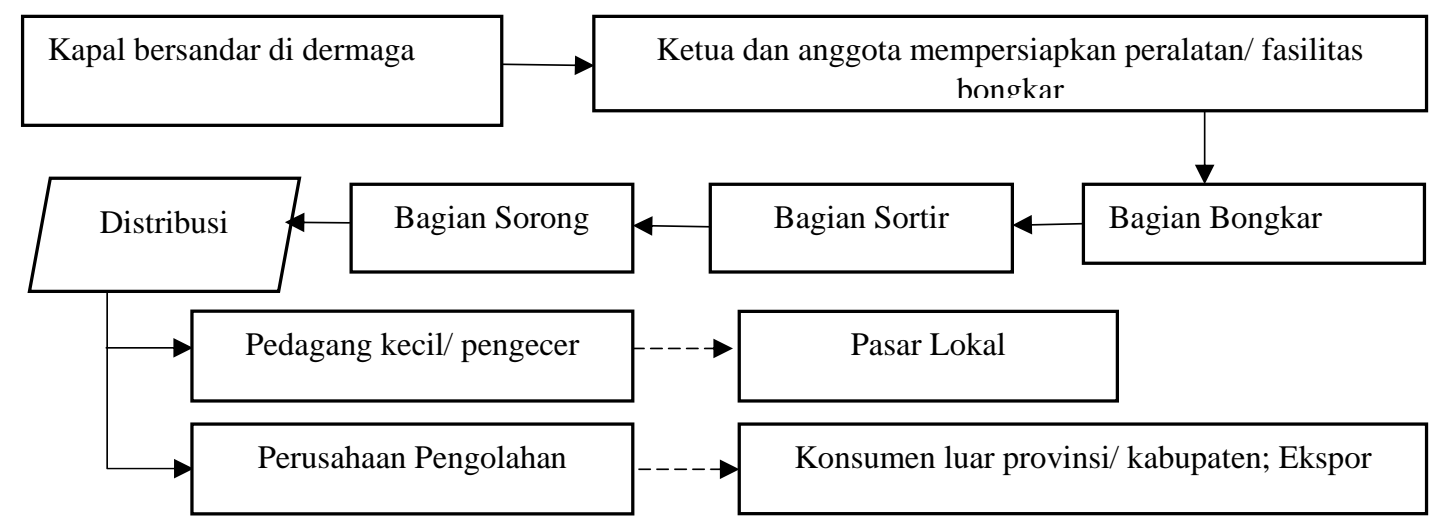

Sumber: Hasil observasi penelitian

Gambar 2 Alur Mekanisme Layanan Bongkar

Mekanisme pelayanan bongkar ikan hasil tangkapan mempunyai alur satu arah dimulai dari kapal bersandar hingga hasil tangkapan ikan dipasarkan. Hasil tangkapan yang dibongkar dari kapal perikanan kemudian akan diteruskan ke bagian sortir. Ikan hasil tangkapan akan disortir oleh pekerja sortir untuk dipilah ikan berdasarkan jenis, ukuran dan kualitas ikan. Setelah di sortir akan berlanjut kepada bagian sorong untuk ditimbang dan di distribusikan ke perusahaan maupun pedagang kecil/ pengecer. Ikan hasil tangkapan yang memiliki kualitas yang kurang baik (reject) juga langsung dipasarkan dan biasanya langsung dibeli oleh pengecer atau pedagang kecil.

Kebutuhan pekerja layanan bongkar disesuaikan dengan banyaknya muatan ikan hasil tangkapan dan jumlah kapal yang melakukan bongkar hasil tangkapan agar ketua bagian bongkar dan sorong dapat membagi jumlah anggotanya jika adanya kapal yang ingin bermuat/mengisi perbekalan. Dengan pemenuhan kebutuhan pekerja bongkar yang mencukupi akan mengurangi lama waktu proses bongkar ikan hasil tangkapan.

\section{Tahapan Aktivitas Bongkar di PPN Sibolga}

Pekerjaan/aktivitas dalam bongkar hasil tangkapan dibagi menjadi beberapa level. Hal bertujuan untuk melihat aktivitas dalam berinteraksi dengan peralatan kerja dan aspek lingkungan kerja. Pekerjaan/aktivitas dibagi atas beberapa level berdasarkan tujuan yang ingin dicapai (Lyons et al. 2004). Level 0 menunjukan aktivitas atau sub-goals yang ingin dicapai. Tahapan aktivitas bongkar di PPN Sibolga dikelompokkan menjadi 7 (tujuh) tahap aktivitas pokok (sub-goa). Pekerjaan ini dipecah menjadi aktivitas dari level tinggi sampai level paling rendah (Lane et al. 2008). Tiap tahapan akan dirinci lebih lanjut menjadi beberapa sub aktivitas. Intensitas kerja tim bongkar meliputi total keterlibatan pekerja berdasarkan jenis aktivitasnya seperti ditunjukkan pada Tabel 3.

\section{Porsi Tanggung Jawab Kerja Tim Bongkar}

Hasil penelitian menunjukkan bahwa untuk aktivitas bongkar ikan hasil tangkapan teridentifikasi 7 aktivitas pokok dimana terdapat total 31 aktivitas. Setiap aktivitas yang melibatkan jumlah tenaga kerja, area kerja dan energi akan berisiko menimbulkan bahaya. Porsi tanggung jawab kerja merupakan suatu tugas yang diberikan dan dibebankan kepada pekerja untuk melakukan pekerjaan secara tuntas dan tidak menunda-nunda waktu sehingga pekerjaan lebih meningkat, bermutu, berkualitas serta dapat dipertanggungjawabkan (Alex 2006). Berikut dilampirkan Gambar 3 porsi tanggung jawab kerja tim bongkar berdasarkan intensitas kerja di Pelabuhan Perikanan Nusantara Sibolga. 
Tabel 3 Aktivitas Bongkar di PPN Sibolga

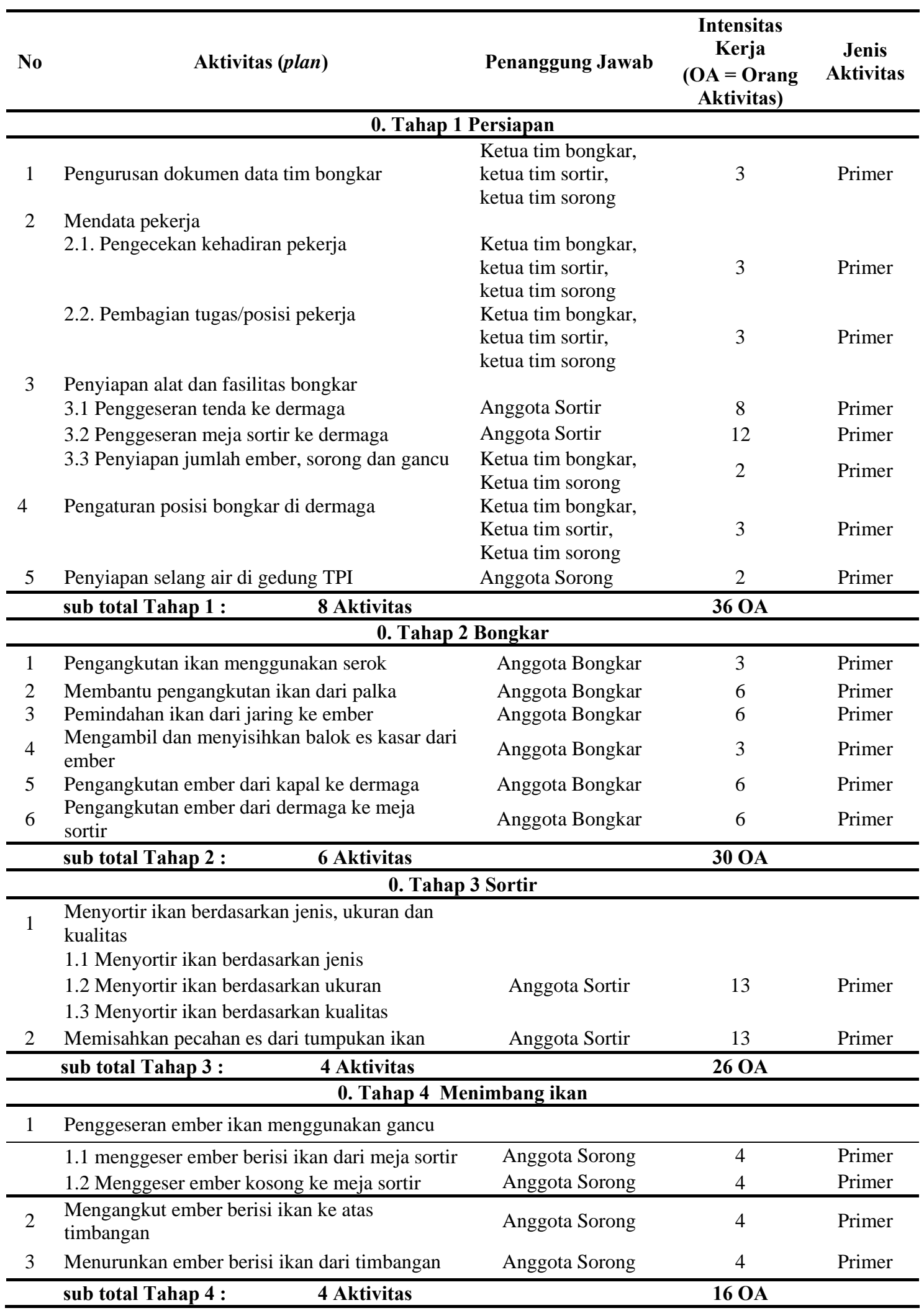




\begin{tabular}{|c|c|c|c|c|}
\hline No & Aktivitas (plan) & Penanggung Jawab & $\begin{array}{c}\text { Intensitas } \\
\text { Kerja } \\
\text { (OA = Orang } \\
\text { Aktivitas) }\end{array}$ & $\begin{array}{c}\text { Jenis } \\
\text { Aktivitas }\end{array}$ \\
\hline \multicolumn{5}{|c|}{ 0. Tahap 5 Pengangkutan } \\
\hline 1 & Mengangkut ember berisi ikan ke atas Sorong & Anggota Sorong & 8 & Primer \\
\hline \multirow[t]{3}{*}{2} & $\begin{array}{l}\text { Mengantar ember berisi ikan menggunakan } \\
\text { sorong }\end{array}$ & & & \\
\hline & $\begin{array}{l}\text { 2.1 Membawa beberapa ember berisi ikan ke } \\
\text { gedung TPI dengan menggunakan sorong }\end{array}$ & Anggota Sorong & 10 & Primer \\
\hline & $\begin{array}{l}\text { 2.2 Membawa beberapa ember kosong dari } \\
\text { gedung TPI dengan menggunakan sorong }\end{array}$ & Anggota Sorong & 10 & Primer \\
\hline \multirow[t]{5}{*}{3} & Apabila terjadi penumpukan & & & \\
\hline & $\begin{array}{l}\text { 3.1 Mengantar ember berisi ikan menggunakan } \\
\text { gancu ke gedung TPI }\end{array}$ & Anggota Sorong & 6 & Sekunder \\
\hline & $\begin{array}{l}\text { 3.2 Mengantar ember kosong menggunakan } \\
\text { gancu ke ruang kerja sortir }\end{array}$ & Anggota Sorong & 6 & Sekunder \\
\hline & sub total Tahap 5: & & $40 \mathrm{OA}$ & \\
\hline & \multicolumn{4}{|l|}{ 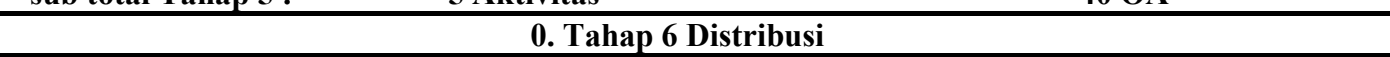 } \\
\hline \multirow[t]{3}{*}{1} & Distribusi ikan di TPI & & & \\
\hline & $\begin{array}{l}\text { 1.1 Mendistribusikan ember berisi ikan dengan } \\
\text { menggunakan gancu ke mobil/truk } \\
\text { perusahaan }\end{array}$ & Anggota Sorong & 6 & Primer \\
\hline & $\begin{array}{l}\text { 1.2 Mendistribusikan ember berisi ikan dengan } \\
\text { menggunakan gancu ke becak bermotor }\end{array}$ & Anggota Sorong & 6 & Primer \\
\hline 2 & Distribusi es ke mobil/truk perusahaan & Anggota Sorong & 4 & Primer \\
\hline & sub total Tahap 6 : & & $16 \mathrm{OA}$ & \\
\hline \multicolumn{5}{|c|}{ 0. Tahap 7 Penggabungan ikan } \\
\hline 1 & $\begin{array}{l}\text { Pengangkutan ember berisi ikan dan } \\
\text { memindahkan kedalam wadah fiber/keranjang } \\
\text { yang ada di dalam mobil/truk }\end{array}$ & Anggota Sorong & 4 & Primer \\
\hline 2 & $\begin{array}{l}\text { Pengangkutan es berisi ikan kedalam wadah } \\
\text { fiber/keranjang yang ada di dalam mobil/truk }\end{array}$ & Anggota Sorong & 2 & Primer \\
\hline 3 & $\begin{array}{l}\text { Menuangkan es ke atas ikan yang sudah } \\
\text { dipindahkan }\end{array}$ & Anggota Sorong & 2 & Sekunder \\
\hline & sub total Tahap 7 : & & $8 \mathrm{OA}$ & \\
\hline
\end{tabular}

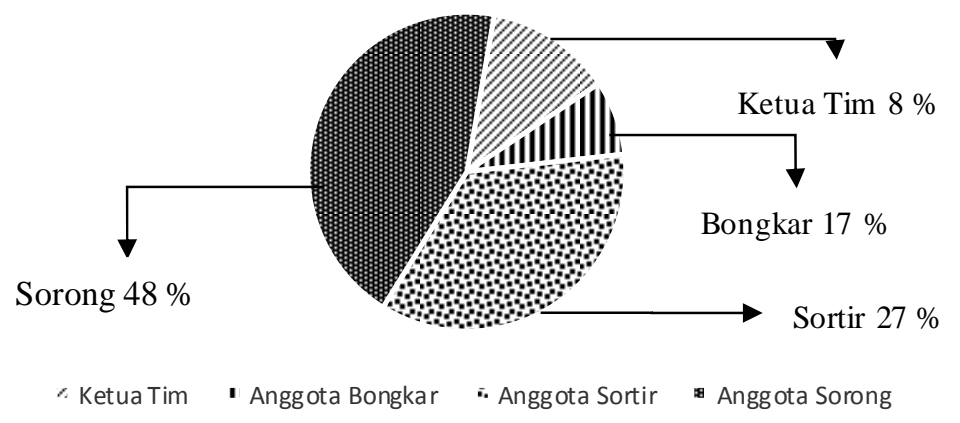

Gambar 3 Porsi tanggung jawab kerja tim bongkar berdasarkan Orang Aktivitas 
Aktivitas tenaga kerja bongkar di Pelabuhan Perikanan Nusantara Sibolga menunjukkan bahwa porsi tanggung jawab kerja yang paling besar adalah bagian/anggota sorong dengan persentasi sebesar 48\% (82 OA), sedangkan bagian/anggota sortir 27\% (46 OA), bagian/anggota bongkar 17\% (30 $\mathrm{OA})$ dan untuk ketua tim dari seluruh bagian tenaga kerja bongkar hanya memperoleh persentasi sebesar 8\% (14 OA). Porsi tanggung jawab kerja dinilai berdasarkan intensitas kerja (OA= Orang Aktivitas) dari masing masing jabatan.

Tahapan bongkar ikan hasil tangkapan mempunyai aktivitas pola satu alur yang berjalan searah hingga hasil akhir. Berbagai aktivitas dalam proses bongkar ikan hasil tangkapan dapat dibagi tugas kerja sesuai dengan bagian masing masing. Nilai tugas kerja adalah penilaian detail dari bagian kerja yang dilakukan oleh tim bongkar sesuai dengan jabatan dan bagian pekerja dari setiap tahapan aktivitas bongkar. Penilaian tugas kerja dilihat dari banyaknya orang kerja dalam setiap tahapan bongkar, dimulai dari tahap persiapan hingga proses bongkar ikan hasil tangkapan berlangsung. Bagian sorong memiliki nilai tugas kerja yang paling besar yaitu sebesar $48 \%$ dari seluruh tahapan aktivitas bongkar dan bagian sortir 27\%, bongkar 17\% dan ketua tim $8 \%$.

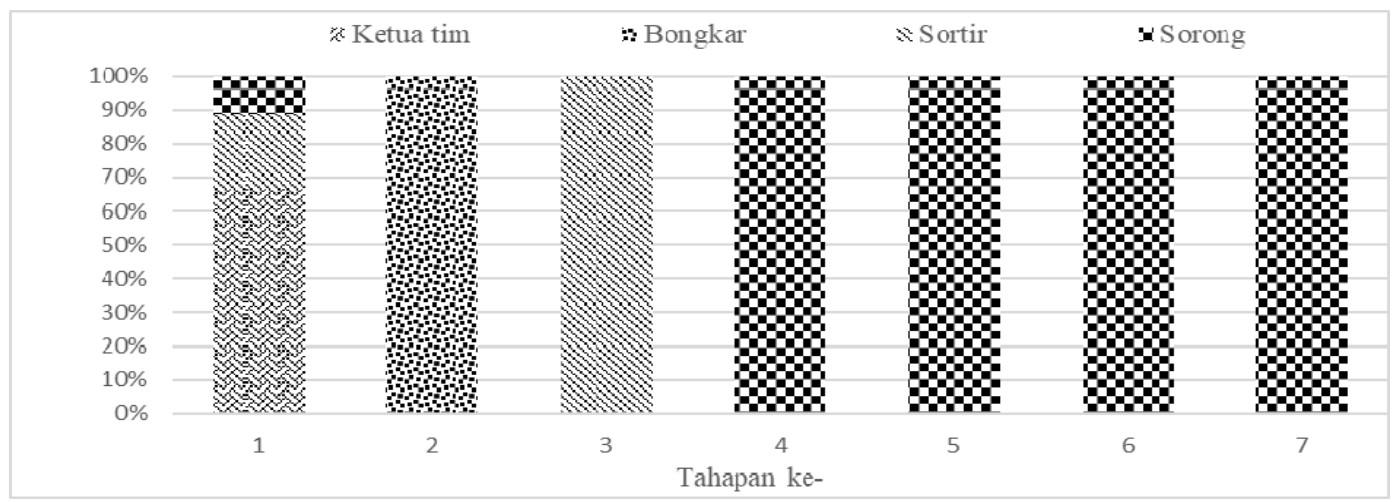

Gambar 4 Persentase kerja tim bongkar per tahapan aktivitas bongkar berdasarkan porsi tanggungjawab

Berdasarkan Gambar 4, pada tahapan ke- 1 ketua tim memiliki porsi tanggung jawab sebesar 62,5\%, bagian sortir sebesar 25\% dan bagian sorong sebesar 12,5\%. Pada tahapan ke- 2 hingga tahapan selanjutnya, aktivitas yang terjadi memiliki tanggung jawab penuh pada bagian masing masing pekerja (bagian bongkar, sortir, sorong). Ketua tim mempunyai tanggung jawab dan tugas penting agar proses bongkar ikan hasil tangkapan dapat berjalan lancar. Pada bagian bongkar, ketua bongkar mengatur posisi anggota untuk membongkar hasil tangkapan seperti anggota yang bertugas untuk pengangkatan sero, pengangkatan ember ke dermaga, pengangkatan balok es dari tumpukan ikan dan lainnya. Pada bagian sortir, ketua sortir mengatur pembagian jumlah anggota sortir dalam setiap meja sortir dan mengatur posisi ember prioritas ikan hasil tangkapan untuk wadah ikan yang akan disortir. Pada bagian sorong, ketua sorong membagi posisi tugas anggota kerja bagian menarik, menimbang, menyorong (menggunakan alat sorong), menyiapkan es, distribusi ikan dan pada kondisi tertentu, ketua sorong akan membagi anggota untuk bongkar dan anggota untuk muat barang kapal.

\section{Intensitas Kerja Tim Bongkar pada aktivitas bongkar ikan hasil tangkapan}

Intensitas kerja tim bongkar merupakan besarnya usaha suatu individu dalam melakukan suatu kegiatan atau pekerjaan dari bagian masing masing kerja. Pada penelitian ini, perhitungan intensitas kerja dilihat dari setiap aktivitas masing-masing bagian yang bekerja. Rincian aktivitas tersebut terdiri dari dua aktivitas yaitu aktivitas primer dan sekunder. Aktivitas primer merupakan aktivitas yang harus atau wajib dilakukan pada urutan tahapan dalam sebuah kegiatan, hal tersebut dikarenakan aktivitas primer akan sangat mempengaruhi keberhasilan dalam proses untuk mencapai sebuah tujuan yang dikehendaki. Aktivitas sekunder merupakan suatu aktivitas yang tidak harus dilakukan 
sesuai urutannya karena aktivitas sekunder merupakan aktivitas pendukung dalam suatu pencapaian, dengan kata lain apabila aktivitas sekunder tidak dilakukan maka tidak akan mempengaruhi aktivitas bongkar, sedangkan apabila aktivitas primer tidak dilakukan maka kegiatan bongkar ikan hasil tangkapan tidak dapat dilakukan (Handayani 2014). Berikut disajikan tabel dan gambar jumlah aktivitas primer dan sekunder.

Tabel 4 Jumlah aktivitas primer dan sekunder tim bongkar

\begin{tabular}{cccc}
\hline Tahap Ke- & \multicolumn{2}{c}{$\boldsymbol{\Sigma}$ Aktivitas } & Total Aktivitas \\
& Primer & Sekunder & \\
\hline 1 & 8 & 0 & 6 \\
2 & 6 & 0 & 2 \\
3 & 2 & 0 & 4 \\
4 & 4 & 0 & 5 \\
5 & 3 & 2 & 3 \\
6 & 3 & 0 & 3 \\
7 & 2 & 1 & $\mathbf{3 1}$ \\
\hline
\end{tabular}

Aktivitas bongkar yang dilakukan oleh tim bongkar memiliki 7 tahapan dengan jumlah total 31 aktivitas, yang terdiri dari 28 aktivitas primer dan 3 aktivitas sekunder. Persentase aktivitas primer sebesar 90\% dibandingkan aktivitas sekunder sebesar 10\%. Tahapan aktivitas pertama (persiapan) memiliki aktivitas primer yang paling banyak, hal ini dikarenakan tahap persiapan merupakan kunci dari kelancaran proses bongkar ikan hasil tangkapan. Jika tahap persiapan tidak terpenuhi, maka aktivitas layanan bongkar ikan hasil tangkapan tidak dapat dilakukan.

Tabel 5 Intensitas kerja tenaga bongkar

\begin{tabular}{|c|c|c|c|c|c|}
\hline Tahap Ke- (i) & IKPi (OA) & IKSi (OA) & IKTi (OA) & Indeks IKPi & Ranking \\
\hline 1 & 36 & 0 & 36 & 0.2278 & 1 \\
\hline 2 & 30 & 0 & 30 & 0.1899 & 2 \\
\hline 3 & 26 & 0 & 26 & 0.1646 & 4 \\
\hline 4 & 16 & 0 & 16 & 0.1013 & 5 \\
\hline 5 & 28 & 12 & 40 & 0.1772 & 3 \\
\hline 6 & 16 & 0 & 16 & 0.1013 & 6 \\
\hline 7 & 6 & 2 & 8 & 0.0380 & 7 \\
\hline Total & 158 & 14 & 172 & & \\
\hline \multicolumn{2}{|c|}{$\begin{array}{l}\text { IKP }=\text { Intensitas Kerja Primer } \\
\text { IKS }=\text { Intensitas Kerja Sekunder }\end{array}$} & \multicolumn{4}{|c|}{$\begin{array}{l}\text { IKT = Total Intensitas Kerja } \\
\text { OA = Orang Aktivitas (satuan unit 'intensitas kerja') }\end{array}$} \\
\hline \multicolumn{6}{|c|}{$\begin{array}{l}\text { Total Intensitas Kerja Primer (IKP) pada aktivitas bongkar adalah } 158 \text { OA dan Total Intensitas } \\
\text { Sekunder (IKS) adalah } 14 \text { OA. Intensitas Kerja Total (IKT) pada aktivitas bongkar hasil } \\
\text { apan adalah } 172 \text { OA. Hal ini berarti bahwa untuk melakukan aktivitas bongkar ikan hasil } \\
\text { apan dari tahapan awal hingga akhir membutuhkan usaha kerja/keterlibatan tenaga kerja setara } \\
\text { an } 172 \text { orang. Indeks IKP dihitung pada tiap tahap aktivitas dan kemudian di ranking. } \\
\text { sarkan tabel yang disajikan ranking aktivitas paling tinggi adalah tahap ke-1 (persiapan) dan } \\
\text { a pada tahap bongkar. Tahap ke-1 memperoleh ranking pertama dengan nilai indeks IKP yang } \\
\text { sar yaitu sebesar } 0.2278 \text {. Tahapan ini mempunyai total } 8 \text { aktivitas ( } 29 \% \text { dari total aktivitas } \\
\text { er) dan memiliki total IKPi tertinggi yaitu sebanyak } 36 \text { OA dibanding aktivitas lainnya. Hal ini } \\
\text { ti bahwa untuk mencapai tujuan seluruh aktivitas pada tahap } 1 \text { (persiapan) membutuhkan usaha } \\
\text { libatan tenaga kerja setara dengan } 36 \text { orang. }\end{array}$} \\
\hline
\end{tabular}


European Foundation for the Improvement of Living and Working Conditions (2001) menyatakan terdapat hubungan yang sangat kuat antara tingkat intensitas dengan masalah kesehatan di satu sisi, dan dengan akibat kecelakaan di sisi lainnya. Pekerja tim bongkar ikan hasil tangkapan yang bekerja dengan intensitas tinggi juga lebih cenderung untuk terjadinya potensi kelelahan dan menyakitkan. Pada aktivitas bongkar ikan hasil tangkapan, bahaya juga dapat terjadi akibat dari ketidakhati-hatian dalam melakukan pekerjaan yang berkaitan dengan peralatan dan melakukan candaan antar sesama pekerja bongkar ikan hasil tangkapan. Intensitas kerja tinggi (high work intensity) merupakan keseluruhan kontribusi negatif terhadap kualitas pekerjaan intrinsik (pokok) yang mengacu pada intensitas usaha tenaga kerja selama waktu pekerjaannya (Eurofound 2012). Andi et al. (2005) menjelaskan bahwa pekerja dengan tingkat kompetensi yang baik diharapkan dapat meminimalisir terjadinya risiko kecelakaan kerja dan dapat membantu meningkatkan kompetensi pekerja yang lain terhadap keselamatan kerja. Dengan intensitas kerja yang tinggi, kurangnya kompetensi yang dimiliki pekerja dalam bagiannya juga memiliki potensi risiko kelelahan (fatigue) dan juga melakukan pekerjaan secara berulang-ulang. Menurut Handayani (2014) akibat dari kelelahan tersebut berpotensi membuat peluang terjadinya kecelakaan kerja semakin besar dan dapat menimbulkan terjadinya kecelakaan di laut karena manusia. Berdasarkan Tabel 5 di atas dengan perolehan nilai indeks yang paling tinggi dari tahapan layanan bongkar berbanding lurus dengan potensi kecelakaan kerja yang besar juga seperti kelelahan atau penyakit akibat kerja.

\section{KESIMPULAN DAN SARAN}

\section{Kesimpulan}

1. Tahapan aktivitas bongkar ikan hasil tangkapan yang dilakukan di Pelabuhan Perikanan Nusantara Sibolga terdapat 7 tahapan. Operasi bongkar ikan hasil tangkapan memiliki aktivitas primer sebanyak 28 aktivitas dan 3 aktivitas sekunder dengan total aktivitas dari tahap awal hingga akhir sebanyak 31 total aktivitas. Pengoperasian bongkar ikan hasil tangkapan dari tahapan awal hingga akhir membutuhkan intensitas kerja sebesar 172 OA (Orang Aktivitas).

2. Intensitas Kerja Primer (IKPi) yang paling besar terdapat pada tahap ke 1 (persiapan) dengan Indeks IKPi sebesar 0.2278 dan terkecil pada tahap ke 7 (penggabungan ikan) dengan Indeks IKPi sebesar 0.0380 dari keseluruhan aktivitas pengoperasian alat tangkap.

Indeks Intensitas Kerja Primer (IKPi) terbesar yang berada pada tahap 1 mengindikasikan risiko kerja terbesar dari seluruh tahapan aktivitas bongkar.

Saran

Pekerja bongkar membutuhkan pelatihan secara berkala terkait meningkatkan kompetensi pekerja dalam aktivitas layanan bongkar.

\section{DAFTAR PUSTAKA}

Alex SN. 2006. Manajemen Personalia. Edisi ke-4. Jakarta (ID): Ghalia Indonesia.

Artoyo AR. 1991. Pengadaan dan Pembinaan Tenaga Kerja Perusahaan. Jakarta [ID]. Balai Pustaka. 73 hlm.

Andi, Alifen RS, Chandra, A. 2005. Model persamaan struktural pengaruh budaya keselamatan kerja pada perilaku pekerja di proyek konstruksi. Jurnal Teknik Sipil Untar. 12(3):127-136.

European Foundation for the Improvement of Living and Working Conditions. 2001. Third European Survey on Working Conditions 2000. Dublin (IE): Luxembourg.72 p. 
Eurofound. 2012. Trends in job quality in Europe. European Working Conditions Survey. 5(2012):94p.doi:10.2806/35164.

Handayani SN. 2014. Intensitas Kerja Aktivitas Nelayan Pada Pengoperasian Soma Pajeko (Mini Purse seine) di Bitung. Jurnal teknologi Perikanan dan Kelautan Vol.5 No.1 Mei 2014: 1-13.

Handayani SN. 2014. Sistem Keselamatan Kerja Nelayan pada Perikanan Soma Pajeko (Mini Purse Seine) di Bitung. [Tesis]. Bogor [ID]: Institut Pertanian Bogor.

Hamilton CT. 2007. 'Work intensity' and the life course perspective: Negotiating boundaries between work and life. Work/Life Intensity: Practices, Patterns and Possibilities. Critical Management Studies; 2007 Jul 11-13; Manchester, Australia. Manchester (AU): Faculty of Business and Enterprise, University of Manchester. 13 p.

Lyons M, Adams S, Woloshynowych M, Vincent C. 2004. Human Reliability Analysis in Healthcare: A Review of Technique. International Journal of Risk \& Safety in Medicine. 16:223-237.

Lane R, Stanton NA, Harrison D. 2008. Hierarchical Task Analysis to Medication Administration Errors. Appl Ergon. 37(5): 669-679.

Maruli SS. 2010. Dampak Tangkahan Terhadap Pendaratan Hasil Tangkapan di Pelabuhan Perikanan Nusantara Sibolga, Tenaga kerja dan Pendapatan Daerah. [Skripsi]. Bogor [ID]. Institut Pertanian Bogor.

Maruli SS. 2010. Pengaruh Keberadaan Tangkahan Terhadap Pendaratan Hasil Tangkapan Pelabuhan Perikanan Nusantara Sibolga. Marine Fisheries 3(1):23-33.

[OHSAS] Occupational Health and Safety Assessment Series 18001. 2007. Sistem Manajemen Keselamatan dan Kesehatan Kerja-Persyaratan. Terjemahan oleh Jack Matatula.

Surat Keputusan Kepala Pelabuhan Perikanan Nusantara Sibolga No: 116/PPNS/KAPPNS/TU.210/I/2018. Sibolga [ID]. Pelabuhan Perikanan Nusantara Sibolga.

Silaban G. 2010. Hubungan antara jumlah kepesertaan tenaga kerja, jumlah kecelakaan kerja, dan jumlah jaminan kecelakaan kerja perusahaan kelompok jenis usaha III peserta program JKK pada PT Jamsostek cabang Medan. Berita Kedokteran Masyarakat. 26(1):12-21. 